\title{
Optimization of Measures to Prevent Collisions of Animals and Road Traffic
}

J. Martolos*

EDIP s.r.o., Pařižská 1, Plzeň

*Corresponding author: martolos@edip.cz

T. Šikula, T. Libosvár

HBH Projekt spol. s r.o., Kabátníkova 216/5, Brno

P. Anděl

EVERNIA s.r.o., tř. 1. máje 97, Liberec

DOI: $10.2478 /$ trans-2014-0010

\begin{abstract}
The movement of animals on roads often causes a collision with vehicles. This not only results in the loss of animal population, but also in social losses - consequences of road accidents. This issue can be dealt with by restricting the movement of animals across roads - most commonly by fencing along roads in combination with construction of overpasses for safe crossing over roads. However, these measures also have their drawbacks - fragmentation of landscape, costs on construction and maintenance. These measures should be designed on the basis of an analysis of migration routes of animals, migration potential of an area (and thus increased movement of animals over a road), and on the basis of characteristics of the traffic flow on a given road. In 2011-2014, EDIP co. together with $\mathrm{HBH}$ Projekt have been working on a research project focused on the methodology for optimization of designing measures which should guide/regulate the movement of animals across the road. EVERNIA co. also participates in the project. The project is financially supported by the Technological Agency of the Czech Republic. The outcome will come in the form of a methodology which becomes a part of the regulations for designing roads.
\end{abstract}

KEY WORDS: Traffic collision, wildlife mitigation, landscape fragmentation.

\section{INTRODUCTION}

Migrations of animals at local, regional and higher than regional levels maintain balance between populations of animals, allow for the exchange of genetic information, even use of food sources and last, but not least they allow for the reactions of animals to changes in the environment and climate. Breaking a migration route by a construction of a road and the subsequent traffic causes stress to animals due to prevented freedom of movement, which may lead to two different situations. First, animals stop migrating and the local 
population losses contact among themselves. The other situation comes in the case of the migration habits of the animals being so strong that instinct overcomes the stress of road crossing. The success of crossing depends on the animal species, road category and traffic volume (EDIP, 2012).

Animals crossing roads cause collisions with vehicles and consequently losses in the population of migrating animals as well as social losses occurring due to road accidents. This issue can be dealt with by regulating animal movement over roads - most commonly by fencing the entire road section in combination with corridors for safe crossing of roads (ecoducts over roads, high capacity bridges, guiding stripes). Large financial resources are spent on the application of different measures to allow for animal migration over roads of different types.

The design of these measures should be realized on the basis of an analysis of animal migration routes and area migration potential.

So far no complex methodology has been developed that would take into account the following:

- real effect of these measures on individual animal populations,

- economic efficiency of these measures,

- necessity of these measures - fencing, ecoducts ("when to implement, and when not yet"),

in relation to traffic volume on roads.

All of the three aforementioned points are closely related to the probability of a potential conflict, which, apart from the frequency of occurrence of different animals, is directly influenced by another factor - character of traffic flow (particularly the gaps between vehicles) at sites of potential collision of vehicles with migrating animals (EDIP, 2007).

\section{PRINCIPLE OF METHODOLOGY}

The methodology is based on an expert evaluation of factors which influence the number of collisions with animals. These effects concern both the road, and the animals.

Regarding the road, particularly the technical road parameters are concerned:

- design road category, road arrangement (number of traffic lanes, their classification),

- horizontal and vertical road alignment,

- parameters and distances of bridges,

- design of areas under bridges,

- design of waterway diversions,

- other technical parameters (road fencing, extent of anti-noise screens, vegetation, alternative vegetation planting, etc.).

Regarding road traffic, traffic volumes are concerned (typically expressed as AADT [veh/day]).

Regarding animals, the following factors are concerned:

- Polygons of unfragmented area by traffic,

- Categorization of the Czech Republic in terms of occurrence and migration of large mammals,

- Long distance migration corridors for large mammals in the Czech Republic,

- Migration important areas,

- Territorial system of ecological stability,

- Biotopes CORINE, 
- Quality category of involved hunting grounds,

- Migration activity of animals,

- Animal categories (according to TP180).

The methodology takes all of these factors into account and tries to quantify them. Since quantification is difficult concerning animals in most cases, the methodology works with point scales.

\section{BASIC DATA ON ACCIDENTS WITH ANIMALS}

Accidents with game (or generally called animals, we use both terms further on in the text as equivalents) make up approx. 5\% of all accidents on the road network in the Czech Republic. 1 person dies with 3900 road accidents every year, 9 are severely injured and 85 are slightly injured. Material damage of these accidents amounts to CZK $155 \mathrm{~m}$ per year (EDIP, 2012).

The evaluation concerned the road accidents recorded by Czech police in 2009-2012 which in their statistical forms contained "collision with game" in the item "Accident type" (see Table 1). Another group concerns accidents when the driver claims his/her behaviour was affected by animal(s) on the road. There are approx. 300 accidents of this type.

Table 1: Road accidents with animals, basic statistics.

\begin{tabular}{|c|c|c|c|c|c|}
\hline \multirow{2}{*}{ Year } & \multirow{2}{*}{$\begin{array}{c}\text { Number of } \\
\text { accidents }\end{array}$} & killed & severely injured & slightly injured & $\begin{array}{c}\text { Material } \\
\text { damage in } \\
\text { million CZK }\end{array}$ \\
\cline { 3 - 6 } & 2804 & 0 & 9 & 61 & 112 \\
\hline 2009 & 3219 & 1 & 3 & 56 & 127 \\
\hline 2010 & 3693 & 3 & 11 & 63 & 145 \\
\hline 2012 & 5953 & 0 & 13 & 157 & 234 \\
\hline Average & $\mathbf{3} \mathbf{9 1 8}$ & $\mathbf{1}$ & $\mathbf{9}$ & $\mathbf{8 4 . 3}$ & $\mathbf{1 5 4 . 5}$ \\
\hline
\end{tabular}

In order to present a more objective comparison, we calculate relative accident rate with animals on individual road categories (and classes) related to road lengths and traffic performance on them (see Table 2, Figure 1 and Figure 2). 
Table 2: Road accidents with animals, relative accident rate.

\begin{tabular}{|l|c|c|c|c|}
\hline & motorway & highways & $\begin{array}{c}\text { secondary } \\
\text { roads }\end{array}$ & tertiary roads \\
\hline $\begin{array}{l}\text { Average number of accidents } \\
\text { with animals } \\
\text { [accidents/year] }\end{array}$ & 199 & 1205 & 876 & 692 \\
\hline $\begin{array}{l}\text { Network length (2010) } \\
\text { [km] }\end{array}$ & 734 & 6255 & 14635 & 34129 \\
\hline $\begin{array}{l}\text { Traffic performance (2010) } \\
\text { [mil. vehkm/year] }\end{array}$ & 7381 & 19337 & 12351 & 7447 \\
\hline $\begin{array}{l}\text { Density of accidents with } \\
\text { animals [accidents / km/year] }\end{array}$ & 0.27 & 0.19 & 0.06 & 0.02 \\
\hline $\begin{array}{l}\text { Relative accident rate with } \\
\text { animals } \\
\text { [accidents / mil. vehkm /year] }\end{array}$ & 0.03 & 0.06 & 0.07 & 0.09 \\
\hline
\end{tabular}

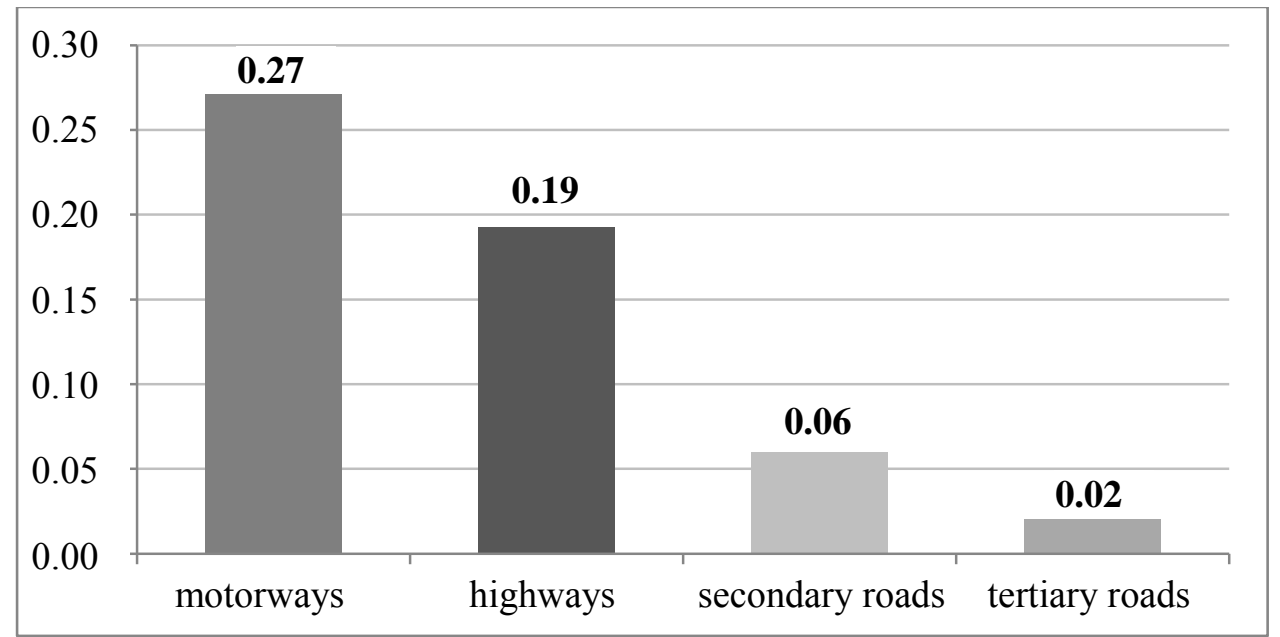

Figure 1: Density of accidents with animals [accidents/km/year].

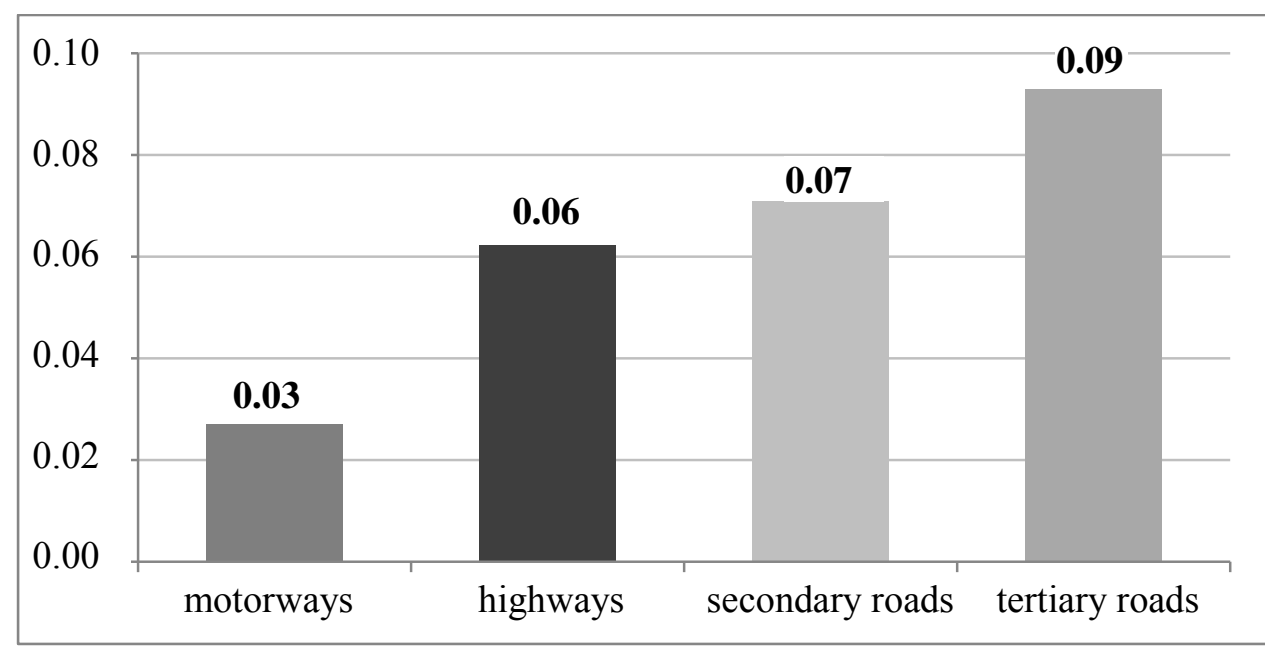

Figure 2: Relative accident rate with animals [accidents/mil.vehkm/year]. 
If we relate the number of accidents with animals to traffic performance (which is an objective indicator or relative accident rate), motorways are the most hazardous and the indicator of relative accident rate grows with decreasing category of road.

\section{MIGRATION PRESSURE}

The evaluation of local migration, or rather migration pressure modelling, is based on the evaluation of ecological migration potential evaluation (MPE), which is described in detail in "TP 180: Migrační objekty pro zajištění průchodnosti dálnic a silnic pro volně žijící živočichy" (Migration structures to provide permeability of roads and motorways for wild animals) (Anděl, 2006). These guidelines form basic frameworks for the designing of migration structures on roads and motorways in the Czech Republic. They define the terms, perform categorization of animals in terms of the requirements for migration structures, and describe recommendations as to technical solutions and dimensions of migration structures. The guidelines introduce the obligation to produce a so-called migration study - evaluation of migration routes of wild animals and design of measures to reduce the road barrier effect - at the stage of investment preparation for building roads. The migration study is a necessary prerequisite for ecological, technical and economic optimization of solutions (Anděl et al., 2011).

In the first stage, MPE is defined on the basis of an analysis of an area and expresses a probability of an area being used for migration (migration pressure before construction). Its evaluation is based on the current and prospective landscape situation. Long-term survey of an area in question is an inseparable part.

The value of MPE can be determined homogeneously for the whole length of a road in question or it can be determined separately for individual road segments and animal categories according to changing conditions of the local environment.

The evaluation of the total ecological migration potential is performed by an educated estimate - synthesis of individual factors which is used for the ratio between positive and negative properties for migration.

The following table shows an overview of possible levels which are defined for individual partial factors of migration pressure. Grey marked boxes indicate that the level is not defined for a given factor.

Table 3: Overview table of individual factor levels.

\begin{tabular}{|l|c|c|c|c|c|}
\hline \multirow{2}{*}{ Individual factor } & \multicolumn{5}{|c|}{ Factor level } \\
\cline { 2 - 6 } & $\begin{array}{c}\text { Factor } \\
\text { significantly } \\
\text { increases } \\
\text { migration } \\
\text { pressure }\end{array}$ & $\begin{array}{c}\text { Factor } \\
\text { increases } \\
\text { migration } \\
\text { pressure }\end{array}$ & $\begin{array}{c}\text { Factor has } \\
\text { no effect } \\
\text { on } \\
\text { migration } \\
\text { pressure }\end{array}$ & $\begin{array}{c}\text { Factor } \\
\text { decreases } \\
\text { migration } \\
\text { pressure }\end{array}$ & $\begin{array}{c}\text { Factor } \\
\text { significantly } \\
\text { decreases } \\
\text { migration } \\
\text { pressure }\end{array}$ \\
\hline $\begin{array}{l}\text { 1. Polygons of unfragmented } \\
\text { area by traffic }\end{array}$ & ++ & + & 0 & & \\
\hline $\begin{array}{l}\text { 2. Categorization } \\
\text { of the Czech Republic } \\
\text { in terms of occurrence and } \\
\text { migration of large mammals }\end{array}$ & ++ & + & 0 & - & - \\
\hline
\end{tabular}




\begin{tabular}{|l|c|c|c|c|c|}
\hline $\begin{array}{l}\text { 3. Long distance migration } \\
\text { corridors for large mammals } \\
\text { in the Czech Republic }\end{array}$ & + & 0 & \\
\hline $\begin{array}{l}\text { 4. Migration important } \\
\text { areas }\end{array}$ & ++ & + & 0 & & \\
\hline $\begin{array}{l}\text { 5. Territorial system of } \\
\text { ecological stability }\end{array}$ & ++ & + & 0 & - & - \\
\hline 6. Biotopes CORINE & ++ & + & 0 & & \\
\hline $\begin{array}{l}\text { 7. Quality of involved } \\
\text { hunting grounds }\end{array}$ & & + & 0 & & \\
\hline $\begin{array}{l}\text { 8. Migration activity } \\
\text { of animals }\end{array}$ & & + & 0 & - \\
\hline $\begin{array}{l}\text { 9. Horizontal alignment } \\
\text { of road segment in question }\end{array}$ & & + & & \\
\hline
\end{tabular}

The synthesis of individual factors can also be performed by the sum of their levels. The resulting value of the total ecological migration potential ranges between 0.0 and 1.0 according to the following table.

Table 4: Evaluation of MPE.

\begin{tabular}{|c|c|c|c|}
\hline $\begin{array}{c}\text { Sum of } \\
\text { individual } \\
\text { factors }\end{array}$ & MPE value & $\begin{array}{c}\text { Ecological } \\
\text { migration } \\
\text { potential }\end{array}$ & Characteristics \\
\hline $10-14$ & $1.0-0.8$ & Very high & $\begin{array}{c}\text { Very important area in terms of migration with all- } \\
\text { year or seasonal migration of animals }\end{array}$ \\
\hline $5-9$ & $0.8-0.6$ & $\begin{array}{c}\text { Above } \\
\text { average }\end{array}$ & $\begin{array}{c}\text { Important area in terms of migration with all-year } \\
\text { or seasonal migration of animals }\end{array}$ \\
\hline $0-4$ & $0.6-0.4$ & Average & $\begin{array}{c}\text { Area with predominant changed biotopes } \\
\text { with scattered (non-concentrated) migration } \\
\text { of animals, which is particularly influenced } \\
\text { by varieties of field crops }\end{array}$ \\
\hline$-1--3$ & $0.4-0.2$ & Below average & $\begin{array}{r}\text { Areas of low importance in terms of migration } \\
\text { of animals, with low quality of biotopes or an area } \\
\text { with obstacles complicating migration }\end{array}$ \\
\hline$-4-6$ & $0.2-0.0$ & None & $\begin{array}{c}\text { Unimportant area near urban development areas } \\
\text { where the occurrence of wild animals is not } \\
\text { expected }\end{array}$ \\
\hline
\end{tabular}




\section{TRAFFIC VOLUME, PROBABILITY OF COLLISION}

In order to determine the probability of a collision of a vehicle and animal, we need to know both the model of vehicle gaps on the road, and behaviour of animals crossing the road (Martolos \& Anděl, 2007). Traffic flow consists of individual vehicles and gaps between them (Medelská et al., 1991). These gaps can be used by animals to cross the road. The frequency of gaps particularly depends on traffic volume. A simple exponential distribution is derived from the Poisson process of the number of vehicles which run through a given place on a road for a time interval $t$, under the assumption of random movement of vehicles on the road (i.e. it is not influenced by other factors, such as vicinity of junction, traffic restrictions, etc.) (Karlický \& Slabý, 1983).

The density of probability of a simple offset exponential distribution of time gaps is in the form of:

$$
f(t)=\frac{I}{3600} e^{-\frac{I}{3600} t}=i e^{-i t}=\frac{1}{T} e^{-\frac{t}{T}}
$$

where I stands for average hour traffic volume, $\mathrm{i}$ is average second traffic volume and $\mathrm{T}$ is average time interval expressed in seconds (Pistulka, 1970).

In order to determine the probability that the time interval $\mathrm{W}$ is higher than $\mathrm{t}[\mathrm{s}$ ], the summation function (summation line) is used. This is given by an equation for a simple non-offset exponential distribution:

$$
P(W>t)=e^{-\frac{I}{3600} t}
$$

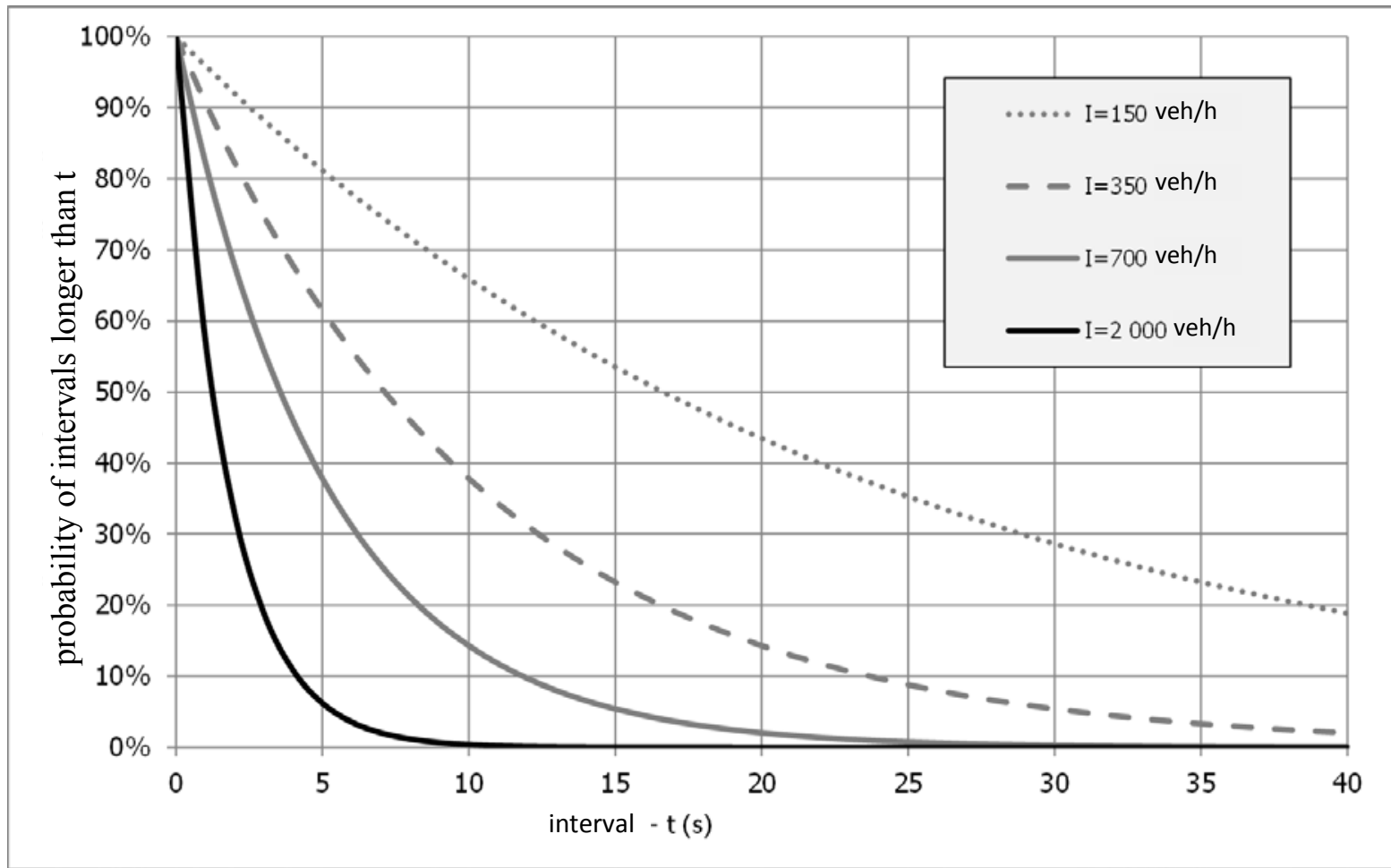

Figure 3: Probability of intervals longer than $t$ (s) for different traffic volumes. 
Figure 3 shows the so-called summation lines of the interval occurrence (i.e. probability of occurrence of an interval longer than the given time) for different traffic volumes.

Since the traffic volume fluctuates during the day (so-called daily variations of traffic volumes) (Martolos, 2012), graphs were created showing the probability of intervals shorter than $\mathrm{t}(\mathrm{s})$ for different hourly traffic volumes - see Figure 4.

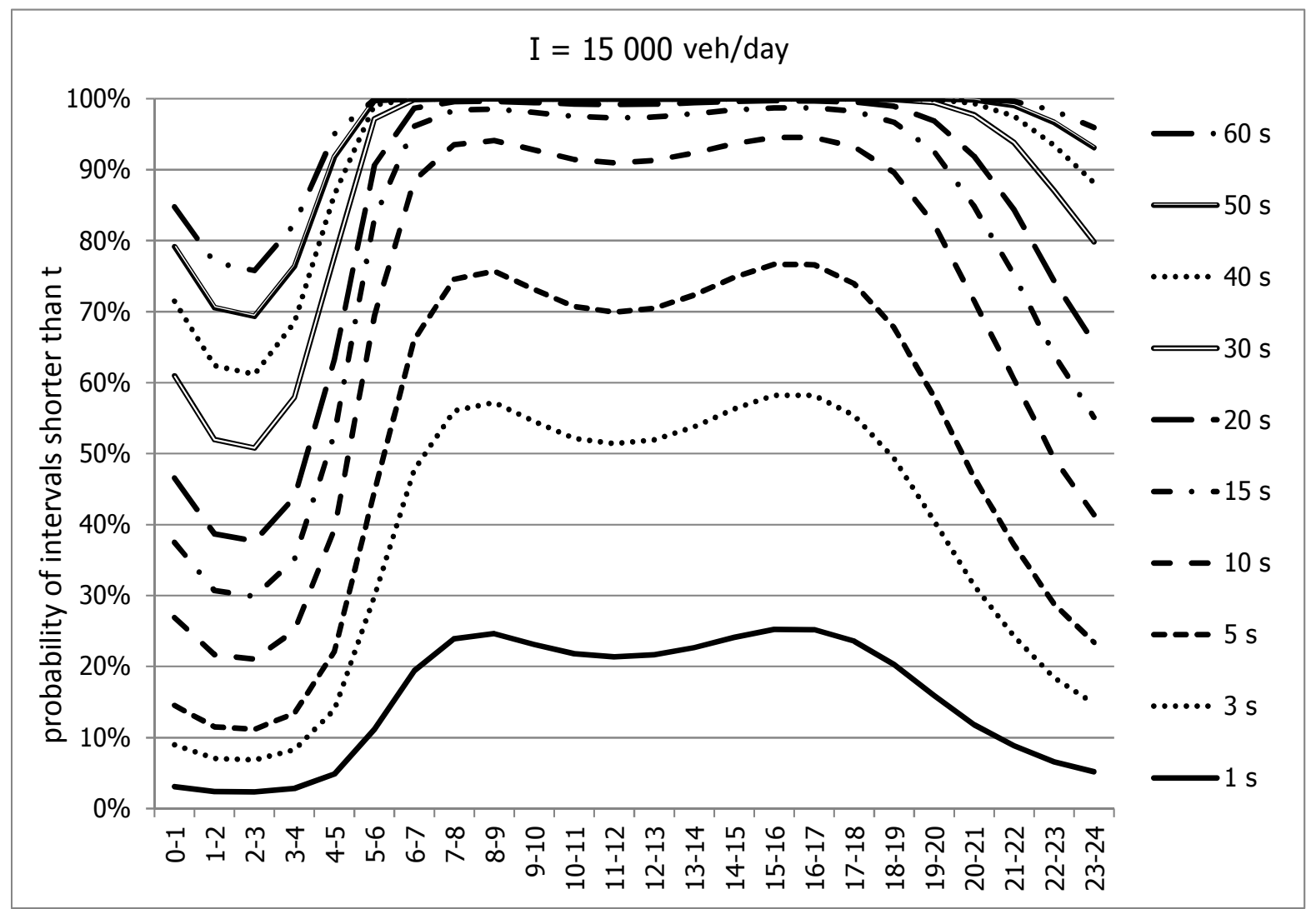

Figure 4: Probability of intervals shorter than $t(s)$ during day.

If we know the time an animal moves for/on the road, which is not an easy task, we are able to calculate a probability of a collision with the given animal. In addition, if we know the distribution of the probability of occurrence of an animal on the road during the day (which can be guessed from the behaviour of individual species and from performed research by photo traps), we are able to calculate the probability of the number of collisions for a given time period (Martolos \& Anděl, 2013).

If we know the migration pressure and collision probability, it is possible to guess the number of hit individuals on a given road segment and evaluate the effectiveness and character of measures for reducing collisions between vehicles and animals.

\section{CONCLUSION}

The answer to the question whether to use a fence or not, or what other measures to use, depends on many factors. Some of them can be clearly defined and specified, but some (as it is very common in the area of ecological issues) can be precisely determined with difficulties. Therefore, there will always be room for professional opinion 
and evaluation of experts on migration who design a solution after taking into account all impacts.

\section{ACKNOWLEDGEMENT}

This article was written within the R\&D project "Methodology of design optimization measures to guide movement of animals across roads" No. TA01030107, funded by the Technology Agency of the Czech Republic.

\section{REFERENCES}

Anděl, P., 2006. TP 180: Migrační objekty pro zajištění průchodnosti dálnic a silnic pro volně žijící živočichy. Liberec: Evernia. (in Czech)

Anděl, P., Belková, H., Gorčicová, I., Hlaváč, V., Libosvár, T., Rozínek, R., Šikula, T., Vojar, J., 2011. Průchodnost silnic a dálnic pro volně žijící živočichy. Liberec: Evernia. 154 p. (in Czech)

EDIP, 2007. Projekt VaV č. 1F55A/065/120 - Využití dopravně inženýrských dat a metod pro kvantifikaci vlivů dopravy na životní prostředí (roční zpráva). (in Czech)

EDIP, 2012. Projekt TA01030107 - Metodika optimalizace návrhu opatření k usměrnění pohybu živočichů přes pozemní komunikace. Odborná zpráva o postupu jednotlivých prací a dosažených výsledcích 2011. (in Czech)

Karlický, K., Slabý, P., 1983. Teorie dopravního proudu (Výběrový předmèt 1). Praha: ČVUT. (in Czech)

Martolos, J., Anděl, P., 2007. Odstupy mezi vozidly v dopravním proudu a pravděpodobnost srážky se zvěří. Silniční obzor, 68 (12), pp. 337-340. (in Czech)

Martolos, J., 2012. TP 189: Stanovení intenzit dopravy na pozemních komunikacích, 2. vydání, Plzeň: EDIP. (in Czech)

Martolos, J., Anděl, P., 2013. Distances between Vehicles in traffic Flow and the Probability of Collision with Animals. Transactions on Transport Sciences, 6 (2), pp. 97-106. ISSN 1802-971X.

Martolos, J., Šikula, T., Libosvár, T., Anděl, P., 2014. Optimalizace opatření k omezení střetu živočichů a dopravy na pozemních komunikacích [Optimization of Measures to Prevent Collisions of Animals and Road Traffic]. In Jandová, V., Mikulová, I., Ličbinský, R. (eds.). VI Czech and Slovak Conference "Transport, Health and the Environment", Brno (Czech Republic), November 10-11, 2014. Brno: Transport Research Centre, pp. 55-62. ISBN 978-80-86502-85-4. (in Czech)

Medelská, M. et al., 1991. Dopravné inženierstvo. Bratislava: Alfa. (in Slovak) 
Pistulka, B., 1970. Způsoby a výsledky analýzy rozdělení časových intervalů dopravního proudu. In „,Modernizace a rozvoj silnic, dálnic a místních komunikaci": seminár̆, Havírov. (in Czech)

NOTICE: The article was taken over from the proceedings of VI Czech and Slovak Conference "Transport, Health and the Environment" held on 10 - 11 November 2014 in Brno (Czech Republic), upon the decision of the proceedings publisher Transport Research Centre and with the consent of the authors of the article.

With the consent of the authors, the article was adapted on the basis of editing instructions of Transactions on Transport Sciences journal and translated into English language. 